\title{
EASTERN ORTHODOX AGREEMENT AND DISAGREEMENT WITH KENNETH COLLINS AND JERRY WALLS
}

\author{
GARY HARTENBURG*
}

Houston Baptist University

\begin{abstract}
In their book, Roman but Not Catholic, Kenneth Collins and Jerry Walls make the case that certain beliefs central to the Roman Catholic faith are unreasonable. This article evaluates, from the point of view of Eastern Orthodoxy, some of the arguments Collins and Walls make. In particular, it argues first that Collins and Walls are correct to criticize John Henry Newman's theory of the development of doctrine as a reason to accept otherwise insufficiently supported Catholic doctrines. Secondly, it offers some points of clarification concerning the matter of sacred tradition and attempts to show the areas of agreement and disagreement between Eastern Orthodoxy and the position that Collins and Walls articulate. Thirdly, it argues that Collins and Walls rely on what is, from an Eastern Orthodox point of view, a questionable view about the interpretation of scripture by assuming without good reason that the clear meaning of scripture is equivalent to the literal interpretation.
\end{abstract}

KEYWORDS: Eastern Orthodoxy, John Henry Newman, development of doctrine, sacred tradition, biblical interpretation

To paraphrase the opening of Thomas Aquinas's prologue to his Contra Errores Graecorum: 'I have studied carefully the book by Kenneth Collins and Jerry Walls, Roman but Not Catholic, which was brought to my attention by Walls himself, and have found expressed in it much that is useful to the affirmation of the Eastern Orthodox faith. I believe, however, that its fruitfulness for many persons could be considerably diminished because of some perplexing statements in it, and so could-and almost certainly willprovide the quarrelsome with the material and occasion for calumny.' At this point, I wish I could continue to paraphrase Thomas by saying that I have also eliminated all ambiguity found in the aforementioned book so that the purest fruit of the faith might be harvested, but either Walls and Collins have written a book more confounding than the one by Nicholas of Durazzo that drew Thomas's scrutiny, or, which is certainly the case, I am incapable of repeating the feats of the angelic doctor. sor of Philosophy at Houston Baptist University. Email: ghartenburg@hbu.edu. 
In any case, there is much in this work with which an Eastern Orthodox Christian can agree with Walls and Collins, but also some with which they cannot. In outline, that agreement and disagreement is as follows.

First, concerning agreement, I think the argument that Collins and Walls make against John Henry Newman's use of his theory of the development of doctrine to support the acceptance of otherwise insufficiently supported Catholic doctrines is decisive. From this point forward, any scholar who wants to use Newman's argument to justify a particular Catholic doctrine on the basis of its development from prior doctrines will need to contend with the criticisms of Newman that Collins and Walls give in this book. However, although I find their criticism of Newman on this point to hit home, I do not agree with all their lines of criticism against Newman. In particular, I find their criticism of Newman's focus on infallibility to be misguided.

Second, concerning the matter of sacred tradition, a matter on which Eastern Orthodox will both agree and disagree with Collins and Walls, I offer some points of clarification and attempt to show the areas of agreement and disagreement.

Lastly, concerning disagreement, I argue that Collins and Walls rely on what is, from an Eastern Orthodox point of view, a questionable view about the interpretation of scripture. In particular, they assume without good reason that the clear meaning of scripture is equivalent to the literal interpretation.

Before proceeding to a discussion of these agreements and disagreements, it seems necessary to point out that 'Eastern Orthodox' today encompasses a variety of people. There are prominent Eastern Orthodox academic theologians of the last fifty years such as Lossky, Zizioulas, Romanides, and Florovsky, who often set themselves in opposition to western modes of theology (see, e.g., Romanides 1982). There are likewise Eastern Orthodox spiritual writers such as Elder Cleopas, who make it a point to distinguish the spirituality of the eastern church from the western. But there are also those who find nothing inherently wrong with what Lossky and others consider to be western forms of theology and spirituality, for example, the dogmatic form of theology as opposed to the mystical (see, e.g., Pomazansky 1994). There are indeed a growing number of Eastern Orthodox philosophers, often trained in the tradition of analytic philosophy, who find ultima facie no real opposition between western modes of theology and the eastern church. Richard Swinburne is a preeminent example of such a philosopher (see, e.g., Vitz 2012; it should be noted that not all the philosopher-theologians in this volume are in agreement with Swinburne regarding the compatibility of western theology and philosophy with Eastern Orthodoxy). This is not to say that these philosophers find nothing about which to disagree with their Roman Catholic and Protestant counter- 
parts, but only that they are not as ready to regard western forms of theology as immediately suspicious. My own sympathies lie with those less suspicious of western forms of theology as well as with the philosophers, but I will try to point out where others in the Eastern Orthodox tradition might respond to Collins and Walls differently.

In what follows I will focus my comments on chapter 2 ('Tradition and the Traditions'), chapter 3 ('Scripture: No Greater Authority?', chapter 4 ('Rome or Nothing?') and chapter 5 ('Revelation, Biblical Authority, and Creed: How to Affirm Catholic Faith without Affirming the Claims of Rome'). I will also draw from a section of chapter 14 ('Protestants in the Crosshairs: Popular Roman Catholic Apologetics'). According to the book's introduction, Collins wrote chapters 2 and 3, and Walls wrote chapters 4, 5, and 14. However, for the sake of simplicity, I will address my comments throughout to both Collins and Walls.

\section{Collins and Walls contra Newman}

In assessing the status of the claims of the Roman Catholic church concerning the authority of the Bible, Collins and Walls begin by noting the claim of the Catechism of the Catholic Church that it is clear therefore that, in the supremely wise arrangement of God, sacred Tradition, Sacred Scripture, and the Magisterium of the Church are so connected and associated that one of them cannot stand without the others' (Catechism 2000: paragraph 95; cited in Collins and Walls 2017: 48). In attempting to elucidate the meaning and defense of this claim, they settle on examining John Henry Newman's argument for the development of Christian doctrine. It is important to note at the outset that the Roman Catholic conception of the connection and association of tradition, scripture, and the Roman magisterium does not in itself stand or fall with Newman's argument about the development of doctrine. However, because Newman's argument is often offered to support the inseparability of tradition, scripture, and Magisterium, rebutting Newman's argument weakens the rational justification for thinking that those three things are interdependent in the way described by the Catechism of the Catholic Church. If Newman's thesis about the development of doctrine is without adequate rational justification, the interdependence of tradition, scripture, and the Roman magisterium might in fact still be as the Catechism describes it, but our rational justification for believing that would be considerably weakened.

As Collins and Walls frame Newman's work, the thesis about the development of Christian doctrine is designed to 'resolve a serious difficulty... [namely] that many of Rome's essential doctrinal claims have scant support at best in the explicit teaching of Scripture as well as the early patristic sources' (Collins and Walls 2017: 50). Newman's way of dealing with this 
serious difficulty was to argue for two theses. We can call the first the infallibility thesis and the second the all-or-nothing thesis.

The infallibility thesis: An original revelation's property of infallibility, which serves as the rational basis for a given doctrine, is also a property of any appropriate development of that original revelation serving as the basis for another doctrine. The all-or-nothing thesis: No Roman Catholic doctrine can be accepted without also accepting every Roman Catholic doctrine, on pain of rational inconsistency.

Since at least some Roman Catholic doctrines were developed from infallible original revelation, these theses taken together would, if true, establish the claim that all current Roman Catholic doctrines must be accepted as true and infallible. And this in spite of the 'scant support at best in the explicit teaching of Scripture as well as the early patristic sources'.

As we will see in more detail below, Collins and Walls reject the infallibility thesis because they reject the goal of infallibility. They reject the all-ornothing thesis because they find no adequate explanation of the necessity relations alleged by Newman and others to hold between Roman Catholic doctrines. [See also Roman but Not Catholic for an example, taken from Pope Pius XII, of what Collins and Walls call 'all-or-nothing reasoning with a vengeance!' (Collins and Walls 2017: 270).]

In general, the Eastern Orthodox church stands with Collins and Walls in rejecting Newman's thesis concerning development. I say 'in general' because the Eastern Orthodox church has not pronounced on matters such as what 'development of doctrine' might mean and whether it has occurred or not. A representative view is expressed by Pomazansky in his Orthodox Dogmatic Theology: 'Each epoch puts forth its own views, ways of understanding, questions, heresies and protests against Christian truth, or else repeats ancient ones which had been forgotten. Theology naturally takes into consideration the inquiries of each age, answers them, and sets forth the dogmatic truths accordingly. In this sense, one may speak about the development of dogmatic theology as a branch of learning. But there are no sufficient grounds for speaking about the development of the Christian teaching of faith itself' (Pomazansky 1994: 47-48; this is consistent with the thesis of Louth 2005, which argues that the central Eastern Orthodox objection to Newman's doctrine of development is its insistence on progress). Furthermore, Newman's suggestion that we ought to accept as true and infallible doctrines that have scant support from early patristic sources is unacceptable to the Eastern Orthodox. As Andrew Louth argues, if development means that there is an historical advance in Christian doctrine, making our understanding of the faith deeper or more profound than that of the Fathers, at least in principle, then such a notion of development cannot be accepted as a category of Orthodox theology' (Louth 2005: 55). 
Collins and Walls think that the infallibility thesis is wrong because it sets out to accomplish too much, namely, infallibility. It is a mistake, according to Collins and Walls, to want appropriate developments from an infallible original revelation to be infallible. We should instead accept a standard lower than infallibility when it comes to assessing Christian doctrines. Secondly, Collins and Walls object to the all-or-nothing thesis because Newman fails to make clear and defend an account of the necessity that ties all pertinent Roman Catholic doctrines together. I find the criticism of the infallibility thesis to be mistaken but the criticism of the all-or-nothing thesis to be on target.

According to Collins and Walls, the person to blame for our modern preoccupation with infallibility is-unjustly, but also no doubt, unsurprisingly-Descartes. 'Descartes's project... appealed to many persons whose sense of certainty had been shaken' in the aftermath of the Reformation (Collins and Walls 2017: 267-68). Although a defense of Descartes's innocence on this count would be too much here, it is clear enough that the rejection of the standard of infallibility as a goal for Christian doctrine by Collins and Walls is too hasty. In the first place, Collins and Walls claim that it has come to be recognized... that Cartesian certainty is an unrealistic standard to expect for human knowledge claims. Many things that we can rightly claim to know—such as basic sense perceptions, memory beliefs, historical beliefs, and so on-fall short of Cartesian certainty' (Collins and Walls 2017: 268). But, of course, Descartes makes no pretension to certainty for the 'many things that we can rightly claim to know' by those-whoever they might be-who have come to recognize the mistake that Descartes is alleged to have made. In Meditations on First Philosophy, Descartes does claim that it is possible to have indubitable knowledge of both God and his own nature, though this claim is not unique to him in the history of ideas. Descartes also explains that it is sufficient that sense perceptions can be reliably trusted on the certain basis that God, being completely and perfectly good, would not create human beings in such a way as to have our sense perceptions systematically mislead us. Of course, our sense perceptions, memories, and so forth will mislead us from time to time, but that can be accounted for in a way that does justice both to our certain knowledge of God and to our human nature.

If Collins and Walls want to contest that, no matter what Descartes himself believed, some philosophy that can nonetheless be described as 'Cartesian' is responsible for the modern Roman Catholic preoccupation with certainty, they will need to give a much stronger defense of their interpretation of the history of the post-Cartesian era than they do.

But more than the misreading of Descartes, the criticism Collins and Walls make of those who aspire to an infallible standard of belief relies on a 
conflation of infallibility and certainty. Collins and Walls move from introducing the concept of 'Cartesian certainty' to speaking of 'absolute certainty' to identifying the quest for 'infallible certainty' as a driving force in some of those who convert to Roman Catholicism (Collins and Walls 2017: 268). But these moves are too hasty, even if the example cited by Collins and Walls of Marcus Grodi, a Calvinist convert to Roman Catholicism, suggests them (Collins and Walls 2017: 268-69). In the first place, certainty is more properly treated as a property of subjective, psychological states. In the case of Grodi, the certainty he seems to be after has at least just as much to do with a feeling of absolute confidence than with the metaphysical necessity of never being mistaken. But the infallibility with which the infallibility thesis is concerned is not a matter of feeling certain. It is more properly construed as concerning truth value: the word of God is infallibly true, not in any psychological sense, even though we should not deny that reading or hearing the word of God may provide occasion for an appropriate feeling of absolute confidence. In other words, the 'hankering for infallible certainty' (Collins and Walls 2017: 269), may be misguided, but the goal of identifying and maintaining an infallible source of knowledge that is developed from an infallible original revelation is not thereby discredited. So much then for the first attempt by Collins and Walls to discredit the infallibility thesis.

In contrast to their criticism of the infallibility thesis, their criticism of the all-or-nothing thesis is decisive. The central issue concerning the all-ornothing thesis is, of course, why the various Roman Catholic doctrines stand or fall together, and on this point they succeed in showing that Newman never provides an adequate explanation. Collins and Walls find in Newman four different accounts:

(D1) All such development as comes upon the original revelation by the necessity of its nature

(D2) All development that occurs as the product of intellectual action upon revelation through successive generations

(D3) All that is necessarily involved in Christian revelation, or evolved from it

(D4) Large accretions on the Christian revelation that profess to be its true and legitimate developments (Collins and Walls 2017: 52-53).

For a number of reasons, which I will not recount here because I agree with them, Collins and Walls find each of these four accounts lacking. Moreover, despite Newman's assumption that these four accounts are essentially equivalent, Collins and Walls deftly show that there are significant differences among them, the most important of which is that D1 and D3 involve some notion of necessity but D2 and D4 do not (Collins and Walls 2017: 5257). As Collins and Walls argue, Newman 'conflates very different kinds of doctrinal developments, namely, (1) those that occur by some sort of neces- 
sity or inevitability and (2) those that occur as the result of intellectual action or reflection on the original revelation throughout successive centuries. By this conflation, he attempts to get us to accept the "large accretions" that claim to be legitimate developments of the original revelation' (Collins and Walls 2017: 74; this conclusion holds even if Chadwick's argument (Chadwick 1957: chapter 5) that Newman's underlying theory of development is based on evolutionary principles rather than strictly logical ones). Attempting to find a suitable explanation of why it's all-or-nothing, Newman veers between accounts that invoke necessity and those that rely on something less than necessary. Equivocation ensues.

\section{Collins and Walls on Sacred Tradition}

Eastern Orthodox and Protestants both reject the Roman Catholic magisterium. But how does the concept of tradition look without the distorting effects of the magisterium? The Eastern Orthodox will, I think, want to caution Collins and Walls to not lose sight of the concept of sacred tradition in their rejection of Newman's argument. In their criticism of Newman, tradition is treated either in a negative sense as the illegitimate attempt of the Roman Catholic church to secure the authoritative interpretation of that tradition for itself or in a positive sense as that which is expressed in the creeds of the early church, in particular the creeds of Nicaea and Constantinople. However, the Eastern Orthodox will want to extend the concept of tradition along the positive trajectory in two ways.

The first is rather straightforward, and is best captured by quoting a famous passage from St. Basil's work On the Holy Spirit (chapter 27), written probably in the 360s: 'Of the dogmas and proclamations that are guarded in the Church, we hold some from the teaching of the Scriptures, and others we have received in mystery as the teachings of the tradition of the apostles. Both hold the same power with respect to true religion. No one would deny these points, at least no one who has even a little experience of ecclesiastical institutions. For if we attempt to reject non-scriptural [unwritten, agraphos] customs as insignificant, we would, unaware, lose the very vital parts of the Gospel, and even more, we would establish the proclamation merely in name. For instance-I will mention the first and most commonwho has learned through the Scriptures that those who hope in the name of our Lord Jesus Christ are marked with the sign of the cross? What sort of scriptural [written, engraphos] text teaches us to turn to the East for prayer? Which saint has left us a scriptural account of the words of the epiclesis at the manifestation of the bread of the Eucharist and the cup of blessing? We are not satisfied with the [Eucharistic] words that the Apostle or the Gospel mentions, but we add other words before and after theirs, since have received non-scriptural teaching that these words have great power in regard 
to the mystery. We bless the water of baptism and the oil of chrism in addition to the very one who is to be baptized. By what Scriptures? Is it not by the secret and mystical tradition? But why? What scriptural authority teaches the anointing itself of oil? Where does a man being immersed three times come from? How much of the baptismal ritual is for the renunciation of Satan and his angels, and what scriptural text does it come from? Does it not come from this secret and unspoken teaching, which our fathers guarded with a simply and unprying silence, since they were well taught that the solemnity of the mysteries is preserved by silence?' (Basil 2011: 104-5). The tradition to which Basil refers has a specific content that remains part of Eastern Orthodox liturgies and rites today.

On the one hand, nothing Basil says about these traditions contradicts anything in the written revelation, but one conclusion Collins and Walls draw from their criticism of Newman is that 'legitimate doctrinal development is constrained by clear scriptural support' (Collins and Walls 2017: 82). That position suggests that Basil's list is non grata. On the other hand, Basil does not present his list as a development of anything. It seems feasible that these matters-or something similar-are what is referred to in 2 Thessalonians 2:15: 'Therefore, brothers, stand fast, and hold the traditions which you have been taught, whether by word [logou], or our letter [epistolês].' Hence, the signing oneself with the sign of the cross and so forth are not, strictly speaking, developments and, perhaps, subject not to the constraint of clear scriptural support but to the weaker constraint that they not contradict the scriptures.

The second positive extension of the concept of tradition, beyond both the creeds of the ecumenical councils and the originally unwritten tradition handed down from the apostles, is less straightforward than the first, but one I think Collins and Walls would agree with. It is the Eastern Orthodox concept of tradition itself. John Anthony McGuckin describes it in the following way: 'The tradition is the Spirit's energy of proclaiming the Gospel and energizing the church's worship and knowledge of God in the present generation, and for future generations to come. The Orthodox, therefore, understand the Holy Tradition to be venerable and hallowed from times past, but to be essentially charismatic, and alive, and full of the power and freshness of the Spirit of God, concerned with bringing new generations to Christ until the end of time: one of the basic functions of his earthly church' (McGuckin 2010: 91). This characterization of tradition is consistent with the position Collins and Walls take on the nature of tradition: "We affirm the value of the oral traditions in the form of the words of Christ as well as the apostolic testimony that preceded the NT canon, testimony that eventually became a part of that canon. We also recognize, as a further example, the tradition of the rule of faith, which, though it can be distinguished from 
Scripture in some sense, nevertheless is consonant with it' (Collins and Walls 2017: 27). McGuckin's description of tradition is also consistent with the descriptions Collins and Walls give of the work of the Holy Spirit at various points in Roman but Not Catholic: the Holy Spirit, they write, plays 'a generous role... in terms of the very inspiration' of scripture (Collins and Walls 2017: 23); 'it is the work of the Holy Spirit that leads the church to discern the divine attributes of Scripture' (Collins and Walls 2017: 69); and 'the church as the living body of Christ is animated by no one less than the Spirit of God' (Collins and Walls 2017: 87). [I am grateful to David Cook for the reference to McGuckin. For a contrary (and minority) Eastern Orthodox view of tradition, see Tarazi 2017: 415-16: 'Whenever the contemporary Corinthians and Thessalonians speak of the "living tradition" that was maintained through the centuries in their cities, they are de facto referring to Paul's teaching. But where does one find that teaching save in his four letters to those cities? To speak of an additional 'oral' tradition is something the Apostle himself categorically forbade... It is the written teaching of Paul to both the Corinthians and the Thessalonians that is read aloud authoritatively to the ears of all Orthodox throughout the world' (emphasis in original).]

In chapter 2, 'Tradition and the Traditions', Collins and Walls describe two types of tradition: Tradition I, which has a single source, namely, the Bible, which is the only unquestioned authority; and Tradition II, which has a dual source, namely, scripture and tradition. This taxonomy of the different senses of tradition would have been more consistent with the statements about the Holy Spirit quoted above if they had made reference to the Holy Spirit in it. In particular, the Eastern Orthodox would prefer to say something between both types of tradition, namely, a tradition that has a single source, the Holy Spirit, a single unquestioned authority that is the source of both scripture and tradition.

\section{Collins and Walls on Interpreting Scripture}

Lastly, I would like to register a concern about the assumptions Collins and Walls make about the interpretation of scripture. In particular, Collins and Walls seem to think that figurative interpretations of scripture are by their nature suspect. They state, 'The reason [for Newman's appeal to the "figurative and indirect" style of Scripture] is obvious: that Marian dogmas have little if any 'direct' support from Scripture, so any viable claim to biblical support must come by way of various figurative interpretations of Scripture' (Collins and Walls 2017: 82). Although the Eastern Orthodox have no interest in defending the Marian dogmas propounded by Rome, they do have an interest in defending the legitimacy of figurative interpretations of scripture that Collins and Walls are too ready to dismiss. 
It is widely acknowledged that the early church fathers in both the east and west were at least willing to countenance figurative interpretations of scripture. As Christopher Hall notes in his work on the interpretation of scripture in the early church, 'Most evangelical students of biblical hermeneutics... would affirm that the grammatical-historical interpretation of a biblical text leads to only one valid meaning-that intended by the author. To add other layers of meaning is to create a hermeneutical labyrinth, a maze in which interpreters will soon find themselves hopelessly confused and lost. The fathers, however, saw the grammatical-historical meaning of a text—what they would probably call its 'literal' meaning-as only one of its possible senses. All the fathers expected to find layers of meaning within a biblical text. The question they posed to each other is in what way and to what degree this layering manifests itself' (Hall 1998: 133, emphasis added). The starting point for the church fathers-both those influential in the western church such as Ambrose, Jerome, Augustine, and Gregory the Great, as well as those influential in the east such as Athanasius, Gregory of Nazianzus, Basil the Great, and John Chrysostom-was to think that figurative interpretations were both possible and expected. The acknowledged differences between the schools of interpretation that developed in Antioch and Alexandria do not stem from a disagreement about whether the biblical text has multiple levels of meaning but from a disagreement about how to interpret the nonliteral levels and how much weight and emphasis should be put on them. (For discussion of Alexandria and Antioch, see Hall 1998: chaps. 6 and 7; see also Perhai 2015.) One way of delineating this emphasis is by distinguishing between allegorical and typological interpretations. In his essay 'Early Interpretation', James Kugel articulates the difference thus: allegorical interpretation is an 'approach to Scripture, whereby biblical persons and incidents become representative of abstract virtues or doctrines or incidents in the life of the soul', whereas typological interpretation is an approach 'whereby parts of the Hebrew Bible are read as a foreshadowing and prediction of the events of the Gospels' (Kugel 1986: 80-81). Though the difference between these two was, as we shall see below, a basis for Calvin's rejection of the former and acceptance of the latter, Hall notes that it is not at all obvious that this distinction was observed strictly by early church fathers (Hall 1998: 133). [In addition to Hall's work, for overviews of how the early church interpreted scripture, see Simonetti 1994 and Kugel and Greer 1986. Some primary sources, principally from Irenaeus and Jerome, are collected in Sadowski 1987.]

A significant source of the early church's agreement that the biblical text has multiple levels of meaning is the example of the apostle Paul. Although the precise meaning of 'allegoroumena' in Galatians 4:24 was disputed by the church fathers, all of them recognized that it at least meant 'nonliteral'. Fur- 
thermore, Paul's extended use of typology concerning Israel and the church in 1 Corinthians 10 served as an inspired model to which later interpreters looked when articulating their own typological interpretations of scripture. (For discussion of Paul's use of typology, see Hays 1993.) Paul's use of 'typos' (1 Corinthians 10:6; Romans 5:14) and 'typikôs' (1 Corinthians 10:11) indicated to the early church fathers that there was legitimate meaning to be found in scripture that was not simply literal. What's more, according to Richard Hays, Paul's use of those particular words 'laid the foundation on which later tradition constructed a distinction between typology and allegory as modes of figurative reading' (Hays 1993: 95). Thus, not one but two types of figurative reading were later understood to be implicated by Paul's own interpretation of scripture, though as noted above the distinction was not always strictly observed.

Hall traces the current 'evangelical' suspicion of multiple levels of meaning to the Enlightenment, but surely there is a tributary flowing from beyond that from at least the Reformation. Calvin, for one, sharply and regularly criticized the use of allegorical interpretation. In his commentary on Genesis 2:8, he states: 'We must, however, entirely reject the allegories of Origin, and of others like him, which Satan, with the deepest subtlety, has endeavored to introduce into the Church, for the purpose of rendering the doctrine of Scripture ambiguous and destitute of all certainty and firmness. It may be, indeed, that some, impelled by a supposed necessity, have resorted to an allegorical sense, because they never found in the world such a place as is described by Moses [i.e., Eden]: but we see that the greater part, through a foolish affectation of subtleties, have been too much addicted to allegories' (Calvin 1847: 114). Readers can find many similar comments throughout the first volume of his commentary on Genesis. [See Calvin 1847: 79 (where Calvin rejects allegorical interpretations of 'firmament' in Genesis 1:6), 142 (where the alleged allegorical sense is contrasted with the 'genuine sense'), 185 (rejecting an allegorical interpretation of the 'turning sword' (Genesis 3:23) as signifying the possibility of repentance), 279 (remarking on the commentaries that ensued from a corruption in the Hebrew text in Genesis 6:12: 'futile allegories followed, just as the curiosity of men is ever desirous of trifling'), 403 (contrasting the allegorical interpretations of Genesis 15 with 'what is more solid', viz., a more literal interpretation), and 447 (where the possibility of evading the evident meaning of Romans 11:16 by means of allegory is foreclosed by the express declaration of Romans 15:8).]

At times Calvin seems to acknowledge that there may be something to allegorical interpretations, but he concludes nonetheless that the balance of evidence counts against them. For example, in commenting on the serpent in Genesis 3, he writes, 'Moses, indeed, says that the serpent was a skillful 
and cunning animal; yet it is certain, that, when Satan was devising the destruction of man, the serpent was guiltless of his fraud and wickedness. Wherefore, many explain this whole passage allegorically, and plausible [plausibilis] are the subtleties which they adduce for this purpose. But when all things are more accurately weighed, readers endued with sound judgment will easily perceive that the language is of a mixed character' (Calvin 1847: 165-66). Although 'plausible' for 'plausibilis' seems straightforward as a translation, it is misleading, at least for today's philosophically-minded readers for whom 'plausible' means something like 'potentially worthy of belief'. Readers without this philosophical slant who read 'plausible' to suggest something specious may be closer to Calvin's meaning, which, I think, is best given by the lexical meaning, 'worthy of applause'. (See, e.g., Cassell's or Lewis and Short, s.v., 'plausibilis'.) Thus, as Calvin has it, we might applaud the subtlety of allegorical interpretation, but 'sound judgment' will lead us to reject it.

However, Calvin, like the early church fathers, cannot ignore the use of figurative interpretation in the biblical text itself. In discussing Noah's ark in Genesis 6, Calvin begins with a criticism of the allegorical interpretations of the ark by Augustine and Origen: 'I purposely pass over the allegorical application which Augustine makes of the figure of the ark to the body of Christ... because I find there scarcely anything solid' (Calvin 1847: 257). (Augustine's allegorical interpretations of the ark are given in book 15 of The City of God and book 12 of Contra Faustus.) He also rejects Origen's allegorical interpretation of the ark by saying that 'there is nothing more profitable, than to adhere strictly to the natural treatment of things.' But his deference to scripture does not allow him to reject figurative interpretation entirely: he follows his comment on Origen by saying, 'that the ark was an image (imaginem) of the Church is certain, from the testimony of Peter (1 Peter 3:21), but to accommodate its several parts to the Church, is by no means suitable.' Thus, he distinguishes between an acceptable typological interpretation of imagery and an unacceptable introduction of an altogether new allegorical meaning, which is essentially the famous distinction he makes in his commentary on Galatians 4:22 between the allegorical interpretations, of Origen in particular, and the 'natural and obvious' meaning of scripture (Calvin 1854: 136).

Because Calvin often singles out Origen for criticism, his rejection of all nontypological figurative interpretations of scripture includes other forms of figurative interpretation that are not strictly allegorical. The most prominent of these, historically speaking, was the contemplative or theoretical interpretation defended by the Antiochene Diodore of Tarsus among others. (Because it is unclear, to me at least, whether Calvin had access to the writings of Diodore, I do not wish to criticize him for neglecting Diodore in 
particular, simply for not addressing the possibility. For a recent detailed study of 'theôria', see Perhai 2015.) Like Calvin after him, Diodore was critical of Origen's method of allegory, but unlike Calvin he did not thereby exclude all nonliteral, nontypological interpretations. As Hall notes, 'while Diodore rejects allegory he does not deny that the literal, historical meaning of a text can lead to a higher meaning, the anagogical sense Antiochene exegetes called theôria [i.e., contemplation]... A key aspect of theôria, however, is that it never eliminates or ignores the underlying literal and historical sense' (Hall 1998: 160).

The approach of Diodore, I think, best approximates present-day Eastern Orthodox interpretations of scripture such as Mary Ford in Ford 2015 and Ford 2017. Ford's account of what the Eastern Orthodox consider proper allegorical interpretation distinguishes 'incarnational' allegory from 'gnostic' allegory; in the former, 'the spiritual level is seen through the literal, while both levels are kept together' (Ford 2015: 85) while the latter regards 'the literal and the visible as essentially containers that have little or no importance once the meaning, or content, has been removed/extracted' (Ford 2015: 85, n. 66). Here we have an admission of nonliteral interpretations that are not merely typographical but whose contemplative meanings are nonetheless constrained by the literal and historical meanings.

Thus, returning to the book under review, when Collins and Walls say that the sort of doctrinal extravagance to which Newman's figurative interpretations give rise are "precisely the sort of extravagance that... the principle of sola Scriptura intends to guard against', and that 'it is our minds (and imaginations) that must be submitted to revelation, and not the revelation submitted to our minds' (Collins and Walls 2017: 12) they recapitulate Calvin's summary dismissal of allegory without acknowledging that there might be nonliteral, nontypological interpretations that are nonetheless constrained by the literal and historical senses. And when they conclude that 'legitimate doctrinal development is constrained by clear scriptural support' (Collins and Walls 2017: 82) they beg the question in favor of identifying 'clear' with 'literal'.

The Eastern Orthodox will have at least three things in response. First, the literal interpretation of scripture is at best a partial account of its meaning. As noted above, the preference for the literal over the figurative results from historical and cultural preferences for such and is not simply a matter with which every Christian, everywhere, at all times has agreed. However, the Eastern Orthodox need not go so far as Newman in his conclusion about the Christian defeat of Marcion, that it may be almost laid down as an historical fact, that the mystical interpretation and orthodoxy will stand or fall together' (Newman 1989: 324). (Though, on closer examination, there is nothing objectionable about saying it may be almost laid down as an 
historical fact'. In Newman's own words, taken literally: we are not compelled to connect mystical interpretation and orthodoxy; it's not completely factual to do so; and the facticity in question is historical, not logical or theological.) Irenaeus depended upon an allegorical reading of the Old Testament to fend off Jewish and Marcionite critics, and he drew close parallels between the fulfillment of prophecy and allegorical interpretation. (See Irenaeus, Against Heresies, 4.26.1, in Sadowski 1987.) However, his predecessor Justin Martyr did not. Hall is right to point out that Justin offers an allegorical interpretation of Noah in the Dialogue with Trypho, but, contra Newman, the central line of argument in Justin's work does not depend at all on allegory, in large part because Justin does not join Irenaeus in merging prophecy and allegory (Hall 1998: 138-139).

Second, there is no necessary connection between a rejection of nonliteral, nontypological interpretations and an adherence to sola scriptura. If we suppose, with the early church fathers, that scripture has meanings other than the literal, then such meanings are genuinely scriptural. They are not an addendum to the literal meaning of scripture but part of its meaning. Throughout their book, Collins and Walls rightly criticize caricatures of sola scriptura-as if it meant that the Bible is the only authority appealed to-and defend its proper characterization 'whereby it norms whatever other authorities have emerged in the life of the church, such as the church fathers' (Collins and Walls 2017: 82). But there is nothing about the proper understanding of sola scriptura that necessitates a rejection of either typological or contemplative interpretations. In fact, acknowledging typological and contemplative interpretations strengthens the norming power of scripture rather than weakens it. Nor do such interpretations affect the perspicuity of scripture, which, as Collins and Walls note, affirms only that the good news of the gospel can be comprehended by all (Collins and Walls 2017: 39; Collins and Walls explain the perspicuity of scripture in more detail than I have summarized here). Of course, if one's goal is to make biblical interpretation a science or a close approximation of one, then the presence of nonliteral, nonhistorical meanings will be frustrating. But that goal is an Enlightenment ideal not shared by the first interpreters of scripture and has no necessary connection with either sola scriptura or the perspicuity of scripture. (See Hall 1998: 25-27, on how Enlightenment ideals have affected our understanding of what interpretation itself is. See also Ford 2015: chapter 6: 'Pseudo-Science as Utopian Solution: A Critical Look at Historical Criticism', and Legaspi 2010.)

This point leads to the third response: when Collins and Walls argue that 'it is our minds (and imaginations) that must be submitted to revelation, and not the revelation submitted to our minds', the Eastern Orthodox are in hearty agreement. Hall points out that in the well-known 'theological ora- 
tions' of Gregory of Nazianzus, the saint argued that theology does not operate 'in a spiritual or devotional vacuum. Rather, who one is, the state of one's spiritual health and devotional well-being, distinctly influences one's ability to interpret Scripture correctly and communicate its truth faithfully' (Hall 1998: 68). It is especially in the context of nonliteral interpretations that the interpreter's sanctification is relevant. If done properly, the reader who pursues figurative interpretations does not let his or her mind and imagination get out from under the authority of revelation; rather, a figurative meaning is discovered when the interpreter submits his or her mind and imagination to the sanctifying power of the Spirit, who thereby enables the interpreter to rightly divide the word of truth.

\section{Bibliography}

Basil (2011) On the Holy Spirit (trans) Hildebrand S. Yonkers, NY: St. Vladimir's Seminary Press.

Calvin J (1854/1948) Commentaries on the Epistles of Paul to the Galatians and Ephesians (trans) Pringle JW. Grand Rapids, MI: Eerdmans.

Calvin J (1847/1948) Commentary on Genesis, vol. 1 (trans) King J. Grand Rapids, MI: Eerdmans.

Catechism of the Catholic Church (2000). Vatican: Libreria Editrice Vaticana.

Chadwick O (1957) From Bossuet to Newman. Cambridge: Cambridge University Press.

Collins K and Walls J (2017) Roman but Not Catholic: What Remains at Stake 500 Years after the Reformation. Grand Rapids, MI: Baker Academic.

Ford M (2015) The Soul's Longing: An Orthodox Christian Perspective on Biblical Interpretation. Waymart, PA: Saint Tikhon's Monastery Press.

Ford M (2017) Reflections on Reading the Scriptures as an Orthodox Christian. Religions 8(7): 122-33.

Hall C (1998) Reading Scripture with the Church Fathers. Downers Grove, IL: InterVarsity.

Hays R (1993) Echoes of Scripture in the Letters of Paul. New Haven, CT: Yale University Press.

Kugel JL and Greer RA (1986) Early Biblical Interpretation. Philadelphia, PA: Westminster.

Legaspi M (2010) The Death of Scripture and the Rise of Biblical Studies. New York, NY: Oxford University Press.

Louth A (2005) Is Development of Doctrine a Valid Category for Orthodox Theology? In Hotchkiss V and Henry P (eds) Orthodoxy and Western Culture: A Collection of Essays Honoring Jaroslav Pelikan on His Eightieth Birthday. Yonkers, NY: St. Vladimir's Seminary Press, pp. 45-63. 
McGuckin J (2010) The Orthodox Church: An Introduction to Its History, Doctrine, and Spiritual Culture. Oxford: Wiley-Blackwell.

Newman J (1989) An Essay on the Development of Christian Doctrine. Notre Dame, IN: University of Notre Dame Press.

Perhai R (2015) Antiochene Theoria in the Writings of Theodore of Mopsuestia and Theodoret of Cyrus. Minneapolis, MA: Fortress.

Pomazansky M (1994) Orthodox Dogmatic Theology: A Concise Exposition, 2nd edition, Seraphim Rose (trans and ed). Platina, CA: Saint Herman of Alaska Brotherhood.

Romanides J (1982) Franks, Romans, Feudalism, and Doctrine. Brookline, MA: Holy Cross Orthodox Press.

Sadowski F, ed (1987) The Church Fathers on the Bible: Selected Readings. New York, NY: Alba House.

Simonetti M (1994) Biblical Interpretation in the Early Church: An Historical Introduction to Patristic Exegesis (trans) Hughes JA. Edinburgh: T\&T Clark.

Tarazi P (2017) The Rise of Scripture. St. Paul, MN: OCABS Press.

Vitz R, ed (2012) Turning East: Contemporary Philosophers and the Ancient Christian Faith. Yonkers, NY: St. Vladimir's Seminary Press. 